\title{
A Repeated Cross-Sectional Study on Japanese Pre-service Teachers' Motivation to Become Elementary and Secondary School Teachers
}

\author{
Hiroki Yoshida
}

\begin{abstract}
School Teachers in Japan are now experiencing a major reformation of the system of teacher training and teacher education. In 2006, the Basic Act on Education was revised for the first time in approximately 60 years, and a teaching certificate renewal system was introduced in 2009 setting a 10 years period of validity of regular and special education personnel certificates. In such a situation, it is anticipated that pre-service teachers' motivation to choose teaching career might also change. This study purposed to identify Japanese pre-service teachers' motivation to become elementary and secondary school teachers, and to identify the change in university students' motivation to become a teacher in the last ten years. As a result, 16 motivation statements were identified as motivation items including five sub-scales: "altruistic motivation," "aspirational motivation," "intrinsic motivation," "extrinsic motivation," and "amotivation" in 2004, while 14 motivation statements were identified consisting three sub-scales: "aspirational motivation," "altruistic motivation," and "intrinsic motivation" in 2014. Moreover, it was revealed that relatively few Japanese university students lack motivation to become a teacher or are motivated by a stimulus coming from outside now.
\end{abstract}

Index Terms-Teacher education, motivation to become school teachers, career guidance, teaching certificate.

\section{INTRODUCTION}

Teachers play a critical role in promoting students' ability and enhancing good learning outcomes. However, it is noted that at present, 58 percent of the countries of the world are short of elementary school teachers and 1.6 million teachers are needed to reach the universal primary education (UPE)-target by 2015 [1]-[3].

The current situation in Japan is not an exception. The number of newly recruited teachers has been increasing these years in elementary and secondary schools. While 9,431 elementary school teachers, 4,226 junior high school teachers, and 3,051 high school teachers were recruited in AY 2003 [4], 13,626 elementary school teachers, 8,333 junior high school teachers, and 4,912 high school teachers were recruited in AY 2013 [5]. This means that employment has increased by 44.48 percent in elementary schools, 97.18 percent in junior high schools, and 61.00 percent in high schools in these ten years. On the contrary, the number of applicants for teacher employment examinations has not increased so much. While

Manuscript received January 5, 2015; revised March 5, 2015. This work was supported by JSPS KAKENHI Grant Number 25350360.

Hiroki Yoshida is with the Tokoha University, Shizuoka, Japan (e-mail: h-yoshida@av-lab.org).
55,011 people applied for elementary school teachers, 55,638 applied for junior high school teachers, and 47,756 applied for high school teachers in AY 2003 [4], 58,703 people applied for elementary school teachers, 62,998 applied for junior high school teachers, and 37,812 applied for high school teachers in AY 2013 [5]. Thus, the number of applicants for elementary school teachers has increased by only 6.71 percent, the number of applicants for junior high school teachers has increased by 13.23 percent, and the number of applicants for high school teachers has decreased by 20.82 percent over the last ten years.

\section{A. The Reformation of the Teacher Training and Teacher Education System in Japan}

The Basic Act on Education sets national aims and goals of education in Japan. The Basic Act defines that "education shall aim for the full development of personality and strive to nurture the citizens, sound in mind and body, who are imbued with the qualities necessary for those who form a peaceful and democratic state and society [6]." It was enacted in March 1947 and was revised in December 2006 for the first time in approximately 60 years [7]-[9].

Along with the revision of the Basic Act Education, revision was also made to the Educational Personnel Certification Law in June 2007 with the purpose of improving the quality of teachers in Japan and to promote the quality of education in schools [10]. Following the revision, a teaching certificate renewal system was introduced in 2009 and a 10 years period was set as the period of validity of regular and special education personnel certificates [11]. In order to renew the period of validity of the education personnel certificate, teachers must take a renewal course given by teacher training universities every ten years [12]. The renewal course consists of 12 hours or more of compulsory topics and 18 hours or more of elective topics.

Furthermore, the Central Education Council [13] announced teacher training universities to establish a graduate school of education that focuses on teaching profession, and a new curriculum module in pre-service teacher education courses, namely, "seminar for teaching practice" was established so as to enhance pre-service teachers' practical teaching skills. In response to the announcement, the Act for Enforcement of the Education Personnel Certification Act was revised in April 2010, and requested teacher colleges to design and manage the new curriculum module "seminar for teaching practice" as a compulsory module for pre-service teacher training. "The seminar for teaching practice" is to be held in the last semester of undergraduate education, and is to observe the following points: 1) classes must adopt active 
learning style seminars, 2) the class size limit is 30 students per class, 3) learning and teaching methods such as cooperative or collaborative group discussions, role-playing, microteaching and field work must be incorporated in the classes, and 4) in-service teachers or former teachers must engage in the teaching process [14].

Thus, a major change in the system of teacher training and teacher education had been introduced in Japan during recent years. As teaching certificates expire in ten years without renewal, it is no longer worthwhile to take pre-service teacher education courses unless students really want to become a school teacher.

\section{B. Motivation to Become a School Teacher}

Many researches have been performed to find out what initially motivates people to become a teacher [15]-[20]. Among those approaches, Richardson and Watt [16] established the FIT-(Factors Influencing Teaching) Choice framework that provides a comprehensive model to investigate why people choose teaching careers [20]. The FIT-Choice framework consists of 12 motivation factors: ability, intrinsic career value, fallback career, job security, time for family, job transferability, shaping future of children/adolescents, enhancing social equity, making social contribution, working with children/adolescents, prior teaching and learning experiences, and social influences. Yet FIT-Choice framework is a valid and reliable model that explains "why people choose teaching careers," since it focuses on the social milieu, it is suggested that it alone cannot explain what motivates people to become teachers. For example results of the International Perspective on Teaching and Learning (TALIS 2013) [21] revealed that an average Japanese teachers work for 53.9 hours $(\mathrm{M}=38.3$ hours $)$, which ranked top of the OECD member countries. It was also reported that only 39.0 percent of the teachers in Japan are females ( $M=68.1$ percent), only 7.4 percent of the teachers work in schools located in areas with 15,000 people or fewer ( $\mathrm{M}=42.0$ percent), 79.7 percent of the teachers commented that their schools lack qualified and/or well-performing teachers $(M=38.4$ percent), and 72.4 percent of the teachers claimed that they are short of support personnel $(\mathrm{M}=46.9$ percent) [21]. It is therefore, necessary to focus on Japanese students' motivation to choose teaching career.

A certain number of researches on Japanese university students' motivation to become a school teacher have been conducted in the past. Mori [22] investigated Japanese and American university students' motivation to choose a teaching career and found out that Japanese university students' motivation to become a school teacher can be classified into two types: intrinsic motivation and extrinsic motivation. Fujiwara and Senzaki [23] conducted a research on 945 university students who belong to the faculty of education and confirmed Mori's research, noting that Japanese university students tend to have high intrinsic motivation to become a school teacher. Wakamatsu and Furukawa [24] researched pre-service teachers and suggested that university students' motivation to become a teacher consists of three clusters: intrinsic motivation, aspirational motivation, and amotivation. Fujiwara [25] asked 344 pre-service teachers why they want to become a teacher and found out that their motivation is four-dimensional: inductive motivation, altruistic motivation, aspirational motivation, and intrinsic motivation. Results of the studies indicate that the change of the Japanese society along with the change of the circumstances of teachers in school might have an effect on people's motivation to choose teaching career.

Therefore, this study aims to identify today's Japanese pre-service teachers' motivation to become school teachers.

\section{PURPOSE}

The purpose of this study is to identify Japanese pre-service teachers' motivation to become elementary and secondary school teachers, and to identify the change in university students' motivation to become a teacher in the last ten years.

The research questions to be addressed in this study are: 1) Why do pre-service teachers in Japan want to become elementary and secondary school teachers? 2) Has pre-service teachers' motivation to become elementary and secondary school teachers changed in these ten years?

\section{STUDY ONE}

Study One was conducted from September 13th to 24th, 2004 , with the purpose of identifying pre-service teachers' motivation to become elementary and secondary school teachers.

\section{A. Participants}

Participants were 95 Japanese third-year university students who participated in elementary and secondary education pre-service teacher education courses. Among them, 54 (56.84 percent) were females and 41 (43.16 percent) were males.

Among the 95 participants, 94 valid responses were collected which means that the response rate was 98.95 percent. Hereinafter, the results of the 94 answers will be introduced and used for data analysis. Table I shows the breakdown of participants by gender and teacher education courses they enrolled.

TABLE I: PROFILE OF PARTICIPANTS (STUDY ONE)

\begin{tabular}{|c|c|c|c|}
\hline \multicolumn{2}{|c|}{ Profile of participants } & \multirow{2}{*}{$\begin{array}{r}\text { Frequency } \\
41\end{array}$} & \multirow{2}{*}{$\frac{\%}{43.62 \%}$} \\
\hline Gender & Male & & \\
\hline & Female & 53 & $56.38 \%$ \\
\hline & Total & 94 & $100.00 \%$ \\
\hline \multirow{5}{*}{$\begin{array}{l}\text { Teacher education } \\
\text { courses enrolled } \\
\text { (multiple answers) }\end{array}$} & Elementary education & 49 & $52.13 \%$ \\
\hline & $\begin{array}{l}\text { Secondary education } \\
\text { (Japanese) }\end{array}$ & 38 & $40.43 \%$ \\
\hline & $\begin{array}{l}\text { Secondary education } \\
\text { (Mathematics) }\end{array}$ & 17 & $18.09 \%$ \\
\hline & $\begin{array}{l}\text { Secondary education } \\
\text { (Social studies) }\end{array}$ & 13 & $13.83 \%$ \\
\hline & $\begin{array}{l}\text { Secondary education } \\
\text { (English) }\end{array}$ & 26 & $27.66 \%$ \\
\hline
\end{tabular}

\section{B. Questionnaire}

A written form of open-ended self-report questionnaire was used to identify participants' motivation to choose a teaching 
career in elementary and secondary schools. Participants were asked why they want to become elementary and secondary school teachers.

\section{Motivation to Become a Teacher}

The KJ method was used to group participants' responses with similar contents or characteristics together. The diagramming process was paneled by an educational technology researcher, a language education researcher, and an educational psychology researcher. As a result, the following 16 statements were determined for the statements for motivation to become a teacher (see Table II).

TABLE II: MOTIVATION TO BECOME A TEACHER (STUDY ONE)

\begin{tabular}{|c|c|}
\hline Items & Frequency \\
\hline \multicolumn{2}{|l|}{ I want to become a teacher because... } \\
\hline 1. I have had inspirational teachers. & 46 \\
\hline 2. I have always wanted to be a teacher. & 39 \\
\hline 3. I enjoy working with children/adolescents. & 38 \\
\hline 4. I want to teach students & 38 \\
\hline 5. I want to listen to children's problems. & 36 \\
\hline 6. I want to help students in their development. & 35 \\
\hline 7. I like children. & 34 \\
\hline 8. I want to facilitate students' learning. & 34 \\
\hline 9. being a teacher is a meaningful job. & 32 \\
\hline 10. I enjoy teaching. & 31 \\
\hline 11. I enjoy studying in the subject area. & 31 \\
\hline 12. I enjoyed my school days. & 31 \\
\hline 13. I want to develop myself & 29 \\
\hline 14. I don't have any particular reasons. & 17 \\
\hline 15. I want to teach club activities & 15 \\
\hline 16. my father/mother is a teacher. & 15 \\
\hline
\end{tabular}

The 16 items of motivation were classified using Hayashi's quantification method type III (correspondence analysis).

Table III shows the normalized category weights given to participants' motivation to become elementary and secondary teachers. According to the tendency of the decrease of the eigenvalues (first axis: 0.5728 , second axis: 0.5069, third axis: 0.2756 , fourth axis: 0.2159 ) and the increase of the cumulative proportion (first axis: 27.15 percent, second axis: 51.18 percent, third axis: 64.25 percent, fourth axis: 74.49 percent), three axes were determined.

Results of the statistical analysis indicate that participants' motivation to become a teacher can be classified into five clusters.
TABLE III: NORMALIZED CATEGORY WEIGHTS TO PARTICIPANTS' MOTIVATION TO BECOME A TEACHER (STUDY ONE)

\begin{tabular}{c|c|c|c}
\hline \hline Category & Axis 1 & Axis2 & Axis 3 \\
\hline \hline
\end{tabular}

I want to become a teacher because...

\begin{tabular}{|c|c|c|c|}
\hline $\begin{array}{l}\text { I enjoy working with } \\
\text { children/adolescents. }\end{array}$ & -1.1234 & 0.2196 & 0.6785 \\
\hline 7. I like children. & -1.1212 & 0.1743 & 0.7293 \\
\hline $\begin{array}{l}\text { I want to help students in their } \\
\text { development. }\end{array}$ & -1.1136 & 0.1978 & 0.6818 \\
\hline 5. I want to listen to children's problems. & -1.0778 & 0.2120 & 0.5448 \\
\hline 13. I want to develop myself. & -0.7057 & 0.1412 & 0.6636 \\
\hline 11. I enjoy studying in the subject area. & -0.6042 & 0.0599 & 0.6274 \\
\hline 12. I enjoyed my school days. & -0.1293 & 0.3310 & -1.7464 \\
\hline 1. I have had inspirational teachers. & -0.0404 & 0.3513 & -1.2246 \\
\hline 9. being a teacher is a meaningful job. & 0.1304 & 0.4247 & -1.0047 \\
\hline 2. I have always wanted to be a teacher. & 0.1952 & 0.2325 & -1.6429 \\
\hline 4. I want to teach students. & 0.8494 & -1.6197 & 0.3109 \\
\hline 8. I want to facilitate students' learning. & 0.9359 & -1.6951 & 0.3408 \\
\hline 10. I enjoy teaching. & 1.0149 & -1.7505 & 0.3892 \\
\hline 15. I want to teach club activities. & 1.3666 & 1.0983 & -0.8745 \\
\hline 16. my father/mother is a teacher. & 2.3533 & 2.2798 & 2.0502 \\
\hline 14. I don't have any particular reasons. & 2.3824 & 2.2890 & 1.2262 \\
\hline
\end{tabular}

The first cluster consists of six items: item \# 3 (I want to become a teacher because I enjoy working with children/ adolescents.), \# 7 (I want to become a teacher because I like children.), \# 6 (I want to become a teacher because I want to help students in their development.), \# 5 (I want to become a teacher because I want to listen to children's problems.), \# 13 (I want to become a teacher because I want to develop myself.), and \# 11 (I want to become a teacher because I enjoy studying in the subject area.), that had high negative category scores on the first correlation axis, comparatively low scores on the second axis, and high scores on the third axis. Since most of the items are related with motivation to help children/adolescents' development, the first cluster was given the name "altruistic motivation."

The second cluster includes four items: \# 12 (I want to become a teacher because I enjoyed my school days.), \# 1 (I want to become a teacher because I have had inspirational teachers.), \# 9 (I want to become a teacher because being a teacher is a meaningful job.), and \# 2 (I want to become a teacher because I have always wanted to be a teacher.), that had relatively low category scores on the first and second axis, and high negative scores on the third axis. All of the four items are related with intense longing to become a teacher or 
respect for their teachers. Therefore, the second cluster was named "aspirational motivation."

The third cluster consists of three items: \# 4 (I want to become a teacher because I want to teach students.), \# 8 (I want to become a teacher because I want to facilitate students' learning.), and \# 10 (I want to become a teacher because I enjoy teaching.), that had high scores on the first axis, highly negative scores on the second correlation axis, and relatively low category scores on the third axis. All of the three items are related with the enjoyment to teach, and therefore was given the name "intrinsic motivation."

The fourth cluster includes one item: \# 15 (I want to become a teacher because I want to teach club activities.) that had high category score on the first and second axis, and comparatively low score on the third axis. The item is not related to classroom teaching nor student guidance and is a motivation stimulus coming from outside so it was named "extrinsic motivation."

The fifth cluster consists of two items: \# 16 (I want to become a teacher because my father/mother is a teacher.), and \# 14 (I don't have any particular reasons.), that had high scores on all of the three axes. As both of the items describe a state of motivational apathy in which participants have little or no reason to choose teaching career, the fourth cluster was given the label "amotivation."

\section{STUdy Two}

Study Two was conducted from September 15th to 26th, 2014 , with the purpose of identifying pre-service teachers' motivation to become elementary and secondary school teachers.

\section{A. Participants}

Participants were 65 Japanese third-year university students who participated in elementary and secondary education pre-service teacher education courses. Among them, 36 (55.38 percent) were females and 29 (44.62 percent) were males.

TABLE IV: PROFILE OF PARTICIPANTS (STUDY TwO)

\begin{tabular}{llrr}
\hline & Profile of participants & Frequency & $\%$ \\
\hline \hline \multirow{2}{*}{ Gender } & Male & 29 & $44.62 \%$ \\
& Female & 36 & $55.38 \%$ \\
\hline \hline & Total & 65 & $100.00 \%$ \\
\hline & Elementary education & 37 & $56.92 \%$ \\
Teacher education \\
$\begin{array}{l}\text { Sourses enrolled } \\
\text { (multiple answers) }\end{array}$ & $\begin{array}{l}\text { Secondary education } \\
\text { (Japanese) }\end{array}$ & 24 & $36.92 \%$ \\
& $\begin{array}{l}\text { Secondary education } \\
\text { (Social studies) } \\
\text { Secondary education } \\
\text { (Science) }\end{array}$ & 12 & $18.46 \%$ \\
& $\begin{array}{l}\text { Secondary education } \\
\text { (English) }\end{array}$ & 5 & $7.69 \%$ \\
\hline \hline
\end{tabular}

All of the 65 participants answered to the questionnaire survey. This means that the response rate was 100.00 percent. Hereinafter, the results of the 65 answers will be introduced.
Table IV shows the breakdown of participants by gender and teacher education courses they enrolled.

\section{B. Questionnaire}

An open-ended self-report questionnaire, which was a written form of free-response style, was used to identify students' motivation to choose teaching career in elementary or secondary schools. Students were asked why they want to become elementary and secondary school teachers.

\section{Motivation to Become a Teacher}

The KJ method was used to group students' motivation statements with similar contents or characteristics together. The procedure was paneled by an educational technology researcher, a language education researcher, and an educational psychology researcher. As a result, 16 motivation statements were determined for the statements for the participants' motivation to become a teacher (see Table V).

TABLE V: Motivation to Become A TEACHER (STUDY Two)

\begin{tabular}{|c|c|}
\hline Items & Frequency \\
\hline \multicolumn{2}{|l|}{ I want to become a teacher because... } \\
\hline 1. I have had inspirational teachers. & 45 \\
\hline 2. I want to help students in their development. & 41 \\
\hline 3. I have always wanted to be a teacher. & 39 \\
\hline 4. I always want to be on my students' side. & 38 \\
\hline 5. I want to listen to children's problems. & 31 \\
\hline 6. I want to enhance students' ability. & 28 \\
\hline 7. I like children. & 22 \\
\hline 8. I enjoy working with children/adolescents. & 22 \\
\hline 9. I enjoy teaching. & 20 \\
\hline 10. I want to facilitate students' learning. & 19 \\
\hline 11. I want to teach students. & 19 \\
\hline 12. I enjoyed my school days. & 18 \\
\hline 13. being a teacher is a meaningful job. & 18 \\
\hline 14. I enjoy studying in the subject area. & 17 \\
\hline 15. I want to develop myself. & 6 \\
\hline $\begin{array}{l}\text { I6. I want to promote students' cooperation in school } \\
\text { events. }\end{array}$ & 2 \\
\hline
\end{tabular}

Among the 16 motivation items decided in Study Two, 13 items were same as the items announced in Study One. On the other hand, three items of Study Two: \# 4 (I want to become a teacher because I always want to be on my students' side.), \# 6 (I want to become a teacher because I want to enhance students' ability.), and \# 16 (I want to become a teacher because I want to promote students' cooperation in school events.) cannot be found in Study One, and three items of study one: \# 14 (I don't have any particular reasons.), \# 15 (I 
want to become a teacher because I want to teach club activities) and \# 16 (I want to become a teacher because my father/mother is a teacher.) are not reported in Study Two.

Participants' responses were classified using Hayashi's quantification method type III. Item \# 15 (I want to become a teacher because I want to develop myself.) and \# 16 (I want to become a teacher because I want to teach club activities.) were deleted from further analysis because few participants commented that they had these two sort of motivation, and if the items were included in the analysis, they put too much category weight to the axes. Thus, 14 anxiety items were selected to be analyzed.

Table VI shows the normalized category weights given to students' motivation to become a teacher. According to the tendency of the decrease of the eigenvalues (first axis: 0.4454, second axis: 0.4090 , third axis: 0.1602 , fourth axis: 0.1133 ) and the increase of the cumulative proportion (first axis: 31.91 percent, second axis: 61.02 percent, third axis: 72.68 percent, fourth axis: 80.80 percent), two axes were determined and interpreted.

TABLE VI: NORMALIZED CATEGORY WEIGHTS TO PARTICIPANTS' Motivation to BeCOME A TEACHeR (STUdy 2)

\begin{tabular}{c|c|c}
\multicolumn{3}{c}{ MOTIVATION TO BeCOME A TEACHER (STUDY 2) } \\
\hline \hline Category & Axis 1 & Axis2 \\
\hline \hline
\end{tabular}

I want to become a teacher because...

\begin{tabular}{|c|c|c|}
\hline 12. I enjoyed my school days. & 1.3553 & 1.8381 \\
\hline 13. being a teacher is a meaningful job. & 1.3110 & 1.7495 \\
\hline 3. I have always wanted to be a teacher. & 0.8263 & 0.6991 \\
\hline 1. I have had inspirational teachers. & 0.5714 & 0.6501 \\
\hline 7. I like children. & 0.1209 & -1.5442 \\
\hline 8. I enjoy working with children/ adolescents. & 0.0358 & -1.3641 \\
\hline 4. I always want to be on my students' side. & 0.2710 & -0.8656 \\
\hline 6. I want to enhance students' ability. & 0.2424 & -0.8345 \\
\hline 5. I want to listen to children's problems. & 0.1742 & -0.8341 \\
\hline 2. I want to help students in their development. & 0.1820 & -0.6945 \\
\hline 14. I enjoy studying in the subject area. & -1.3516 & 1.0252 \\
\hline 11. I want to teach students. & -2.0394 & 0.6371 \\
\hline 10. I want to facilitate students' learning. & -2.0394 & 0.6371 \\
\hline 9. I enjoy teaching. & -1.9428 & 0.5918 \\
\hline
\end{tabular}

Results of the statistical analysis suggest that students' motivation to become elementary and secondary school teachers can be classified into three clusters.

The first cluster consists of four items: item \# 12 (I want to become a teacher because I enjoyed my school days.), \# 13 (I want to become a teacher because being a teacher is a meaningful job.), \# 3 (I want to become a teacher because I have always wanted to be a teacher.), and \# 1 (I want to become a teacher because I have had inspirational teachers.), that had high category scores on both of the correlation axes. As all of the four items are related with participants' motivation to become a teacher or respect for their teachers, the first cluster was given the name "aspirational motivation."

The second cluster includes six items: \# 7 (I want to become a teacher because I like children.), \# 8 (I want to become a teacher because I enjoy working with children/adolescents.), \# 4 (I want to become a teacher because I always want to be on my students' side.), \# 6 (I want to become a teacher because I want to enhance students' ability), \# 5 (I want to become a teacher because I want to listen to children's problems.), and \# 2 (I want to become a teacher because I want to help students in their development.), that had relatively low category scores on the first axis and high negative scores on the second axis. All of the six items are related with motivation to support children/adolescents growth. Therefore, the second cluster was named "altruistic motivation."

The third cluster consists of four items: \# 14 (I want to become a teacher because I enjoy studying in the subject area.), \# 11 (I want to become a teacher because I want to teach students.), \# 10 (I want to become a teacher because I want to facilitate students' learning.), and \# 9 (I want to become a teacher because I enjoy teaching.), that had highly negative scores on the first correlation axis and high scores on the second axis. All of the four items explains participants' motivation to teach, and therefore was given the name "intrinsic motivation."

\section{DISCUSSIONS}

The purpose of the current study was to identify Japanese pre-service teachers' motivation to become school teachers, and to identify the change in their motivation to choose a teaching career in the last ten years. The design of the study included two steps: Study One which was conducted in September, 2004 and Study Two which was performed in September, 2014.

Regarding the first research question "Why do pre-service teachers in Japan want to become elementary and secondary school teachers?," results of the questionnaire surveys show that more than 40 percent of the pre-service teachers who took teacher education courses in 2004 mentioned that they want to become a school teacher because they had inspirational teachers, they have always wanted to be a teacher, they enjoy working with children/adolescents, and they want to teach students. On the other hand, students enrolled in teacher education courses in 2014 replied that they want to become a teacher because they had inspirational teachers, they want to help students in their development, they have always wanted to be a teacher, they want to be on their students' side, they want to listen to children's problems, and they want to enhance students' ability.

Moreover, statistical analysis using quantification method type III suggests that participants' motivation to become a 
teacher of Study One can be explained by five factors: "altruistic motivation," "aspirational motivation," "intrinsic motivation," "extrinsic motivation," and "amotivation." In the meanwhile, participants' motivation to choose a teaching career of Study One can be classified into three groups, namely, "aspirational motivation," "altruistic motivation," and "intrinsic motivation."

Referring to the second research question "Has pre-service teachers' motivation to become elementary and secondary school teachers changed in these ten years?," results of two studies indicate that Japanese pre-service teachers' motivation to become school teachers has not changed in a large degree. Most of the participants in both of the study have high altruistic motivation, aspirational motivation, and intrinsic motivation. It is suggested that Japanese pre-service teachers desire to become a school teacher because they want to work with and support children or adolescents in their development, they were inspired by their teachers and consider a teacher a meaningful job, and they enjoy teaching children or adolescents. These findings are consistent with Fujiwara's [25] research results. However, two motivation factors: extrinsic motivation and amotivation that were found in Study One cannot be found in Study Two. Results of the studies suggest that relatively few Japanese pre-service teachers today lack motivation to become a teacher or are motivated by a stimulus coming from outside.

\section{CONCLUSION}

Results of the current study suggest that Japanese pre-service teachers' motivation to choose a teaching career has not changed significantly in these ten years. However, it is suggested that most of the students taking teacher education courses now purely desire to become a school teacher and to work with and teach children/adolescents.

As previously explained, pre-service and in-service teachers in Japan are experiencing a major reformation of teacher training and teacher education. Under the teaching certificate renewal system, it means little to just take teacher education courses without strong motivation to become a teacher. That must be the key reason of the change of students' motivation to choose a teaching career. Thus, the implication of the teaching certificate renewal system might lead to promote students' intrinsic and/or altruistic motivation to become teachers. It is also suggested that the teacher license renewal system promotes the improvement of in-service teachers' capacity by periodically requiring teachers to become familiar with new teaching techniques and information, and eliminates incompetent teachers and maintains quality of education at a certain level [26]. On the other hand, the new teacher license system could lead to the decrease of the number of students who wish to become a school teacher.

As the participants of the present study were Japanese university students who are taking teacher education courses in university, it is recommended to use other samples from other ages, nationality, and prior teaching experience. As Fujiwara [25] suggests that students' high school life has effects on their motivation to choose teaching career, it is meaningful to ask high school students who wish to enter teacher education universities why they want to become teachers.

Given the findings of this study, it is expected to examine the relationships between pre-service teachers' motivation to choose a teaching career and their belief in education, self-efficacy in teaching, prior teaching experience, and other educational, psychological, and personal variables. For example, Haruhara [27] insists that university students' motivation to choose teaching career affects their self-efficacy in teaching, and Imae and Shimizu [28] and Haruhara [29] suggests that students' their experience of teaching practice affects their motivation to become teachers.

In addition, the findings of this study are expected to contribute to suggest teacher educators how to promote students' motivation to become teachers, and consequently lead to produce highly motivated quality teachers to elementary and secondary schools.

\section{ACKNOWLEDGEMENT}

This work was supported in by a grant from the Japan Society for Promotion of Science (JSPS) KAKENHI Grant Number 25350360.

\section{REFERENCES}

[1] UNESCO Institute for Statistics. (October 2013). A Teacher for Every Child: Projecting Global Teacher Needs from 2015 to 2030. [Online]. Available:

http://www.uis.unesco.org/Education/Documents/fs27-2013-teachersprojections.pdf

[2] The EFA Global Monitoring Report team, Teaching and Learning: Achieving Quality for All, Paris, France: UNESCO, ch. 1, pp. 42-107, 2014.

[3] UNESCO Institute for Statistics. (October 2014). Wanted: Trained Teachers to Ensure Every Child's Right to Primary Education. [Online]. http://unesdoc.unesco.org/images/0022/002299/229913E.pdf

[4] Ministry of Education, Culture, Sports, Science and Technology-Japan. (December 2003). The status of the implementation of teacher employment examinations in AY 2003. [Online]. Available: http://www.mext.go.jp/a_menu/shotou/senkou/03122502.htm

[5] Ministry of Education, Culture, Sports, Science and Technology-Japan. (December 2013). The status of the implementation of teacher employment examinations in AY 2013. [Online]. Available: http://www.mext.go.jp/a_menu/shotou/senkou/1343166.htm

[6] Ministry of Education, Culture, Sports, Science and Technology-Japan. (December 2006). Basic Act on Education (Provisional Translation). [Online]. http://www.mext.go.jp/english/lawandplan/1303462.htm

[7] Ministry of Education, Culture, Sports, Science and Technology-Japan, FY 2005 White Paper on Education, Culture, Sports, Science and Technology: Efforts in Education Rebuilding / Realization of a Nation Based on Culture and the Arts, Tokyo, Japan: Ministry of Education, Culture, Sports, Science and Technology, ch. 1, pp. 3-30, 2006.

[8] Ministry of Education, Culture, Sports, Science and Technology-Japan. (December 2006). About the New Basic Act on Education. [Online]. Available: http://www.mext.go.jp/b_menu/kihon/houan.htm

[9] Ministry of Education, Culture, Sports, Science and Technology-Japan, The Development of Education in Japan 2005-2008, Tokyo Japan: Ministry of Education, Culture, Sports, Science and Technology, part II, ch. 1, pp. 60-64, 2008.

[10] Elementary and Secondary Education Bureau, MEXT 2007, Tokyo, Japan: Ministry of Education, Culture, Sports, Science and Technology, pp. 8-9, 2007.

[11] Ministry of Education, Culture, Sports, Science and Technology, FY 2007 White Paper on Education, Culture, Sports, Science and Technology: Promoting Educational Reforms Based on the Revised Basic Act on Education/Reform of Elementary and Secondary Education to Usher in a New Era of Education, Tokyo, Japan: 
Ministry of Education, Culture, Sports, Science and Technology, ch. 1 , pp. 5-17, 2008.

[12] National Institute for Educational Policy Research. (March 2011). Teacher training and certificate system. [Online]. Available: http://www.nier.go.jp/English/educationjapan/pdf/201103TTCS.pdf

[13] Central Education Council. (November 2006). How Teacher Education Should be Conducted in the Future. [Online]. Available: http://www.mext.go.jp/a_menu/koutou/kyoin/1268600.htm

[14] Teacher Education Accreditation Board. (March 2008). Points to consider for conducting the seminar for teaching practice. [Online]. Available:

http://www.mext.go.jp/component/a_menu/education/detail/__icsFile s/afieldfile/2013/02/25/1267752_05.pdf

[15] D. Alexander, D. Chant, and B. Cox, "What motivates people to become teachers," Australian Journal of Teacher Education, vol. 19, no. 2 , pp. 40-49, 1994.

[16] P. W. Richardson and H. M. G. Watt, "Who chooses teaching and why? profiling characteristics and motivations across three Australian universities," Asia-Pacific Journal of Teacher Education, vol. 34, no. 1, pp. 27-56, March 2006.

[17] H. M. G. Watt and P. W. Richardson, "Motivational factors influencing teaching as a career choice: Development and validation of the FIT-choice scale," Journal of Experimental Education, vol. 75, no. 3, pp. 167-202, 2007.

[18] C. Sinclair, "Initial and changing student teacher motivation and commitment to teaching," Asia-Pacific Journal of Teacher Education, vol. 36, no. 2, pp. 79-104, March 2008 .

[19] J. Williams and H. Forgasz, "The motivations of career change students in teacher education," Asia-Pacific Journal of Teacher Education, vol. 37, no. 1, pp. 95-108, February 2009.

[20] G. Anthony and K. Ord, "Change-of-career secondary teachers: Motivations, expectations and intentions," Asia-Pacific Journal of Teacher Education, vol. 36, no. 4, pp. 359-376, November 2008

[21] OECD, TALIS 2013 Results: An International Perspective on Teaching and Learning, Paris France: OECD Publishing, pp. 31-425, 2014.

[22] T. Mori, "Factors that affect japanese and american university students motivation to become a school teacher: Applying research methods of the field of behavioral science to comparative education," Educational Studies, vol. 36, no. 3, pp. 12-21, March 1969.

[23] M. Fujiwara and T. Senzaki, "Career building for pre-service teachers (1): University students' motivation to become a school teacher and belief in education," Bulletin of the Japanese Society for Study of Career Guidance, vol. 5, pp. 1-5, May 1985.

[24] Y. Wakamatsu and T. Furukawa, "Study on the factors that affect the change of pre-service teachers' motivation to become a school teacher," Bulletin of the Japanese Society for Study of Career Guidance, vol. 17, no. 2, pp. 19-29, May 1997.

[25] M. Fujiwara, "The motivation to be a school teacher and his or her high school and university day's life: About successful applicants of teacher's employment test," Bulletin of the Faculty of Education, vol. 38, pp. 75-81, March 2004.

[26] H. Higashiyama and K. Hara, "The teacher license renewal system in japan: the case study of bukkyo university," Bulletin of the Faculty of Education, vol. 21, pp. 125-137, March 2010.

[27] Y. Haruhara, "The Relationships between motivation to become teachers, self-efficacy in teaching, and participants parents: with focus on first-grade university students enrolled in teacher education courses," Research Bulletin of School Education, vol. 21, pp. 1-10, March 2010

[28] K. Imae and H. Shimizu, 'Effects of the university students' experience of teaching practice on their motivation to become teachers: A pre-post study," Educational Technology Research, vol. 17, no. 4, pp. 185-195, 1994

[29] Y. Haruhara, "Effects of university students' experience of teaching practice on their motivation to become teachers: With focus on students enrolled in the faculty of education," Research Bulletin of School Education, vol. 17, pp. 17-26, March 2008.

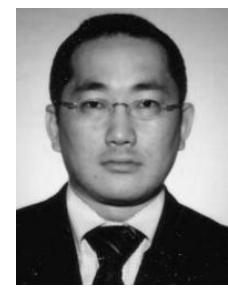

Hiroki Yoshida was born in Nara, Japan in 1973. He received the MEd degree in educational methodology (audio-visual education) from International Christian University, Tokyo, Japan in 2001.

He worked at the Japan Audio Visual Education Association (JAVEA) from April, 2000 to March, 2002. He has been teaching pre-service teachers in Tokoha University in Shizuoka, Japan since April, 2002. He is currently a professor at the Faculty of Education, Tokoha University. His research interests include teacher education, online learning, cooperative learning, and hypermedia education. 